\title{
SISTEM INFORMASI LOKASI SEJARAH PAHLAWAN SULAWESI SELATAN MENGGUNAKAN ALGORITMA SEQUENTIAL SEARCH BERBASIS ANDROID
}

\section{INFORMATION SYSTEMS OF SOUTH SULAWESI HEROES HISTORICAL LOCATION USING SEQUENTIAL SEARCH ALGORITHM BASED ON ANDROID}

\author{
Pujianti Wahyuningsih $1^{1}$, Nur Mustika $2^{2}$ \\ ${ }^{12}$ STMIK Handayani Makassar 1 \\ 1ujiwahyuningsih@ handayani.ac.id 1, ${ }^{2}$ mustika@
}

\begin{abstract}
Abstrak
Indonesia adalah negara yang memiliki pahlawan di setiap daerahnya, salah satunya adalah daerah Sulawesi Selatan. Salah satu kendala pada generasi muda saat ini adalah kurangnya pengetahuan dan pemahaman tentang sejarah pahlawan daerah. Tujuan penelitian ini untuk membangun sistem informasi lokasi sejarah pahlawan dengan algoritma sequential search berbasis android. Pada metode sequential search merupakan metode pencarian secara bertahap mulai dari awal sampai akhir dalam mencapai titik yang diinginkan. Hasil dari penelitian ini adalah dapat menampilkan informasi sejarah pahlawan dan informasi Sulawesi Selatan. Aplikasi ini juga menampilkan lokasi tempat sejarah yang berada di Sulawesi Selatan sehingga pengguna aplikasi ini dapat menemukan jalur yang tepat untuk mencapai titik yang diinginkan.
\end{abstract}

Kata kunci : Metode Sequential Search, Android, Pahlawan Nasional Indonesia

\begin{abstract}
Indonesia is a country that has heroes in every region, one of which is South Sulawesi. One of the obstacles for the younger generation today is the lack of knowledge and understanding of the history of regional heroes. The purpose of this study is to build a hero historical location information system with an android-based sequential search algorithm. The sequential search method is a search method in stages from beginning to end in reaching the desired point. The result of this research is to show historical information about heroes and information about South Sulawesi. This application also displays the location of historical places in South Sulawesi so that users of this application can find the right path to reach the desired point
\end{abstract}

Keywords: Sequential Search Method, Android, Indonesian National Heroes

\section{PENDAHULUAN}

Negara Indonesia merdeka 17 Agustus 1945, dalam memperoleh kemerdekaannya erat hubungannya dengan peran para pahlawan. Negara Indonesia terdiri atas beberapa provinsi yang memiliki pahlawan untuk mencapai kemerdakaan. Setiap provinsi memiliki pahlawan- pahlawan yang memiliki peran melawan penjajah. Salah satu provinsi yang meiliki banyak sejarah pahlawan adalah provinsi Sulawesi Selatan. Provinsi Sulawesi selatan memiliki beberapa kota yang setiap terdiri atas kabupaten dan kecamatan.

Seiring zaman teknologi berkembang semakin pesat, sehingga generasi muda berfokus pada pengembangan dari teknologi dan perekonomian negara. Namun dengan perkembangan tersebut 
sehingga membuat generasi muda melupakan perjuangan para pahlawan dalam memperoleh kemerdekaan. Tidak dapat dipungkiri peran teknologi menjadi hal yang utama saat ini, salah satu contohnya adalah perkembangan smartphone. Generasi muda lebih mengikuti kemajuan dari smartphone dari semua tipe. Penggunaan smartphone lebih cenderung digunakan untuk sosmed, facebook, Instagram, tik-tok dan sebagainya. Smartphone memilki peran yang penting dalam proses pembelajaran, penggunaannya alat tersebut diharapkan mampu memberikan dampak positif. Namun smartphone lebih cenderung digunakan bukan sebagai media pembelajaran melainkan sebagai media hiburan yang lebih banyak kearah yang negatife. Generasi muda lebeih mengenal para artis entertainment daripada tokoh pahlawan. Dalam memperkenalkan sejarah pahlawan maka peran serta generasi muda adalah hal yang penting. Maka sebaiknya generasi muda lebih memahami sejak dini sehingga dapat menumbuhkan rasa cinta tanah air dan nasionalisme kepada negaranya.

Sulawesi Selatan merupakan provinsi yang mempunyai beberapa pahlawan yang cukup terkenal. Adapun tokoh yang terkenal di Sulawesi selatan adalah pahlawan dari gowa yaitu Sultan Hasanuddin[1] dan Syekh Yusuf al- Makassary. Kedua pahlawan ini memiliki nilai - nilai karakter pada pahlawan nasional, karakter yang dimiliki adalah falsafah huma betang, mamut menteng, isen mulang. Adapun nilai- nilai sebagai berikut: nilai acca (kecakapan), nilai lempu (kejujuran), nilai warani (keberanian), nilai getting (keteguhan). Pada penelitian sebelumnya membahas tentang sejarah pahlawan Sulawesi Selatan dengan metode direct Search[2]. Pada penelitian tersebut dapat memberikan informasi kepada seseorang untuk mengetahui sejarah pahlawan terkhususnya pada daerah Sulawesi Selatan. Penelitian tersebut mempermudah dalam memperoleh informasi dengan bantuan mobile phone sehingga dapat mengetahui informasi dimana pun dan kapan pun. Informasi yang diberikan memberikan manfaat kepada pembacanya tetapi untuk mengetahui secara detail tentang sejarah tersebut maka terkadang seseorang tertarik untuk mengunjungi lokasi dari sejarah tersebut. Ketertarikan terhadap lokasi dari tempat sejarah sehingga peneliti berinisiatif membuat sistem untuk memberikan lokasi.

Pencarian lokasi sudah diteliti sebelumnya pada penelitian terdahulu. Adapun penelitian mengenai pencarian lokasi adalah sebagai berikut: Pada penelitian[3], Peneliti membuat sistem informasi pariwisata untuk mengetahui jalur terdekat dalam memperoleh lokasi pariwisata pada daerah Timor Leste. Upaya yang dilakukan daerah Timor Leste dengan menambahkan pencarian lokasi untuk meningkatkan jumlah pengunjung wisatawan didaerah tersebut. Pada penelitian[4], Peneliti membuat aplikasi untuk mengetahui lokasi wisata kota Jakarta denga algoritma sequential search sehingga membantu wisatawan dalam memperoleh letak lokasi yang ingin dikunjungi. Pada penelitian[5], Peneliti menerapkan algoritma a-star dalam menemukan lokasi fotografi. Penggunaan penerapan aplikasi ini dapat membantu untuk mengetahui spot atau lokasi yang memiliki nilai estetika untuk mengambil gambar sesuai akses rule yang diinginkan pada daerah bandar Lampung. Pada Penelitian[6], peneliti membuat aplikasi untuk memudahkan dalam mencari arsip -arsip pada instansi pelayanan puskesman di kampong Bali Bengkulu dengan menggunakan algoritma Sequential Searching.

Pada Penelitian ini peneliti akan membangun sebuah sistem informasi lokasi sejarah pahlawan Sulawesi Selatan dengan menggunakan metode sequential search dengan menggunakan android. Pada penelitian sebelumnya [2], peneliti telah membuat sistem untuk memberikan informasi tentang sejarah pahlwan dari Sulawesi Selatan, sehingga pada penelitian ini peneliti mengembangkan sistem yang dibangun dengan menambahkan lokasi dari sejarah pahlawan sehingga bagi yang ingin mengetahui lebih detail dapat dengan mudah mengunjungi lokasi dari tempat bersejarah yang ingin diketahui. Pencarian lokasi yang ingin dikunjungi dapat diakses melalui mobile phone sehingga dapat mempermudah dalam proses pencarian lokasi tesebut. 


\section{MATERIAL DAN METODOLOGI}

\subsection{Metode Sequential Search}

Metode sequential search merupakan pencarian nilai secara berurut yang dimulai dari elemen awal dan akhir hingga elemen yang ingin dikunjungi dapat ditemukan dari sebuah list[7]. Metode ini dapat digunakan pada data yang berurut dan tidak berurut. Proses pada pencarian ini cukup sederhana yaitu menyesuaikan data secara berurut satu persatu hingga data akhir untuk mendapatkan nilai yang sesuai dalam mencari lokasi yang diinginkan oleh pengguna.

Metode sequential search pada penelitian ini adalah pengguna mencari lokasi dari pahlawan yang ingin diketahui sehingga aplikasi akan memberikan informasi tentang lokasi yang ingin dituju. Pengguna dapat dengan mudah mengetahui rute untuk mencapai titik dari lokasi tersebut dengan menggunakan mobile phone. Pada penggunaan metode ini terdapat langkah- langkah dalam proses pengaplikasiannya. Adapun langkah- langkah dari metode ini dapat dilihat pada flowchart yang terdapat pada gambar 1 .

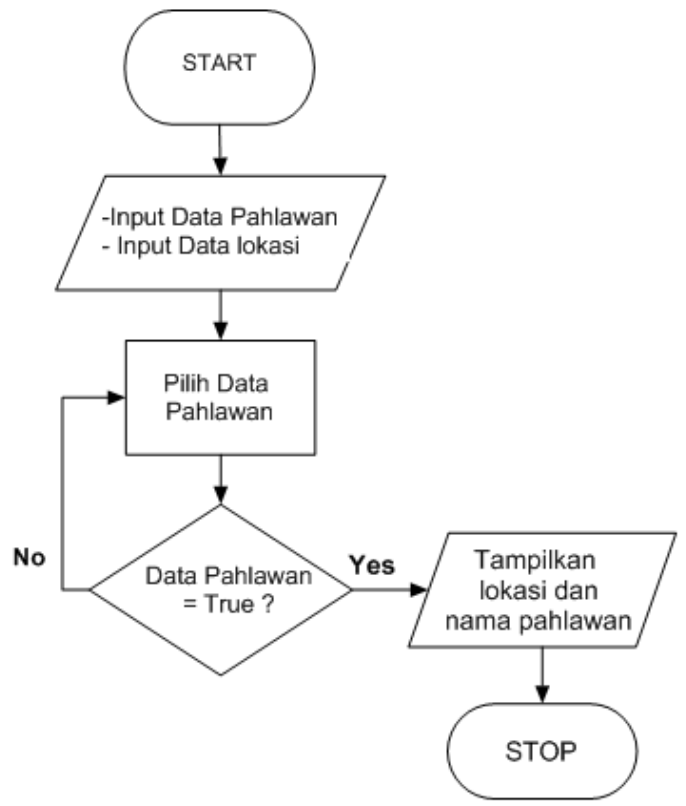

Gambar 1. Flowchart sequential search

Pada gambar 1 flowchart sequential search menjelaskan langkah awal yang dilakukan pengguna adalah mengakses aplikasi sejarah pahlawan kemudian menginput data pahlawan dan lokasi pengguna berada. Setelah data pahlawan dipilih dan sesuai dengan yang diinginkan maka aplikasi akan menunjukkan lokasi pahlawan yang ingin dikunjungi beserta nama pahlawan. Lokasi akan menunjukkan lokasi yang ingin dituju dan rute yang akan dilalui untuk mecapai titik lokasi pahlawan tersebut, sehingga pengguna lebih muda untuk menemukan rute yang tepat dalam mencapai titik yang diinginkan. Jika data pahlawan yang dituju tidak sesuai dengan yang diinginkan maka akan kembali untuk memilih data pahlawan yang ingin dikunjungi. Sistem ini akan berhenti jika dikeluarkan oleh pengguna.

\subsection{Android}

Android merupakan sistem operasi smartphone dan tablet yang banyak digunakan saat sekarang ini[2]. Android sudah banyak diteliti oleh para peneliti sebelumnya. Adapun penelitian yang 
membahas tentang android adalah sebagai berikut. Pada penelitian[8], Peneliti menggunakan sistem operasi android untuk mengidentifikasi terumbu karang dengan menggunakan smartphone. Penggunaan animasi dalam mengaplikasikan sistem tersebut membuat daya tarik dengan tampilan 3D sehingga memudahkan pengguna dalam mengetahui terumbu karang. Pada penelitian[9], peneliti membangun aplikasi dalam memesan bus tiket sehingga pengguna tidak perlu untuk mengunjungi loket penyedia tiket. Penggunaan dalam melakukan pemesanan yaitu dengan smartphone yang menggunakan sistem operasi android dapat dilakukan lebih mudah dan lebih cepat.

\subsection{Pahlawan Nasional Indonesia}

Indonesia memilki banyak pahlawan di setiap daerahnya sebagai contoh pahlawan nasional di daerah Sulawesi Selatan. Pahlawan Nasional Indonesia adalah pejuang yag telah berjuang untuk mencapai kemerdakan dengan menumpahkan darah dalam membela negara Indonesia. Atas perjuangan yang dilakukan maka mereka mendapatkan gelar[10] atas sebuah prestasi yang dilakukan sehingga mereka berhak mendapatkan sebutan sebagai pahlawan nasional dan telah diberikan SK dari presiden Republik Indonesia. Pada penelitian ini peneliti akan membangun sebuah sistem untuk mengetahui sejarah dari pahlawan di Sulawesi Selatan dan dapat mengertahui lokasi dari pahlawan tersebut, sehingga pengguna dapat lebih memahami sejarah dengan mengunjugi lokasi pahlawan.

\subsection{Sistem yang diusulkan}

Sistem yang diusulkan pada penelitian adalah pengguna yaitu sebagai wisatawan atau masyarakat yang ingin mengetahui sejarah pahlawan di daerah Sulawesi Selatan dan ingin mengunjungi tempat- tempat bersejarah yang terdapat di daerah Sulawesi Selatan. Sistem ini dapat mempermudah pengguna untuk mencapai rute dengan menginput lokasinya sehingga pengguna dapat memilih jalur yang kemudian akan mengarahkan pengguna ke lokasi tujuan. Pengguna juga dapat melihat ringkasan secara umum mengenai sejarah pahlawan di daerah Sulawesi Selatan. Berikut gambar use case diagram sistem yang diusulkan.

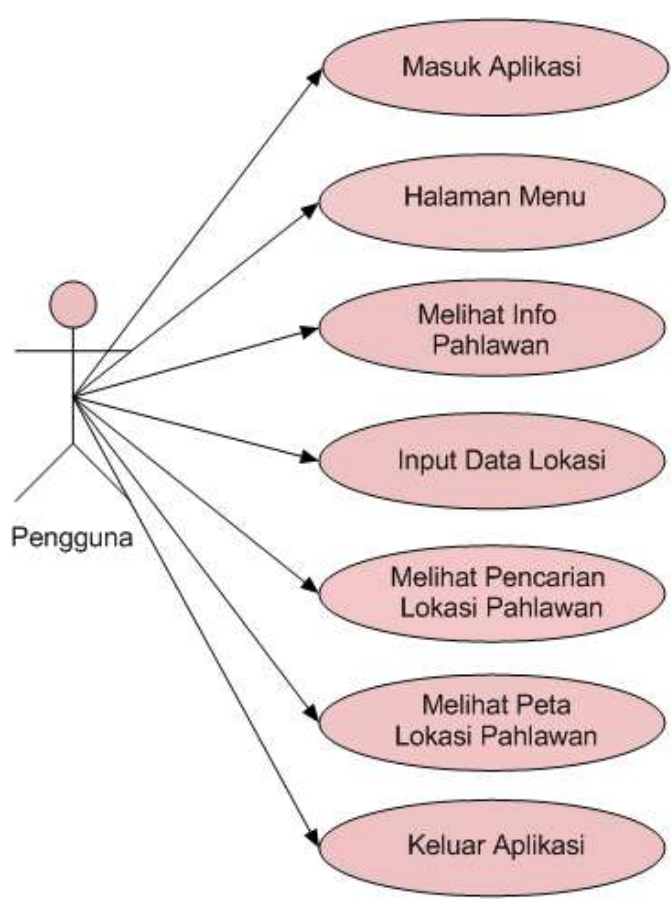

Gambar 2. Sistem yang diusulkan 


\section{PEMBAHASAN}

Sistem informasi pada penelitian ini dapat diakses melalui perangkat mobile phone yang menggunakan sistem operasi terbuka yaitu berbasis android. Pada aplikasi yang dibangun tidak menggunakan database. Pada proses pembuatan aplikasi admin akan memasukkan seluruh data pahlawan yang ada didaerah Sulawesi Selatan. Data yang dimasukkan berupa nama pahlawan, ringkasan secara umum pahlawan atau sejarah pahlawan dan tidak lupa admin juga memasukkan ringkasan umum mengenai provinsi Sulawesi Selatan. Setelah semua data telah dimasukkan maka tahap selanjutnya yang dilakukan adalah menginstal pada aplikasi mobile phone. Berikut tampilan awal ketika pengguna mengakses aplikasi sejarah pahlawan.

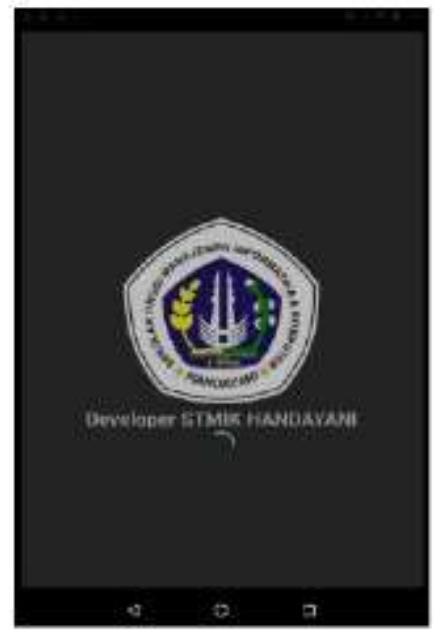

Gambar 3. Tampilan awal sistem

Gambar 3, merupakan tampilan awal yang akan ditunjukkan pada sistem jika pengguna pertama kali membuka sistem informasi sejarah pahlawan Sulawesi Selatan. Sistem ini dibuat oleh developer bernama STMIK Handayani. Setelah pengguna mengakses aplikasi, maka tahap selnajutnya yang akan ditampilkan pada aplikasi ini adalah halaman utama. Berikut gambar halaman utama pada aplikasi sistem informasi sejarah pahlawan.

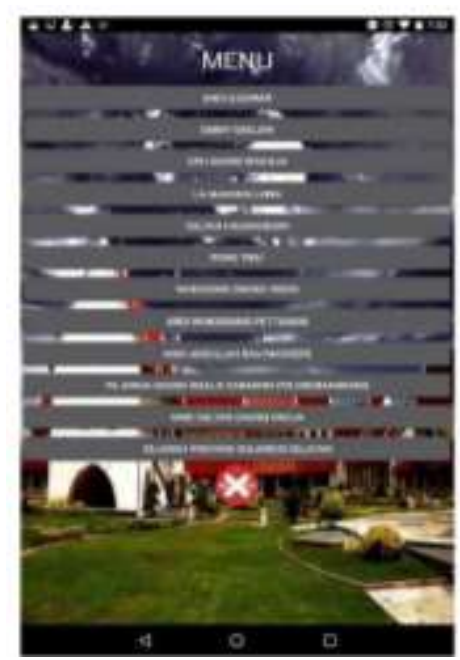

Gambar 4. Halaman utama Aplikasi 
Gambar 4, merupakan halaman utama yang menunjukkan beberapa pahlawan yang terdapat didaerah Sulawesi Selatan. Pada Halaman utama akan menampilkan ringkasan secara umum mengenai sejarah pahlawan daerah Sulawesi Selatan dengan cara pengguna memilih salah satu nama pada sistem tersebut. Setalah pengguna telah memilih salah satu nama maka pengguna dapat membaca secara umum mengenai sejarah pahlawan. Selain itu pada aplikasi ini juga memberikan informasi mengenai ringkasan tentang provinsi Sulawesi Selatan. Berikut tampilan ringkasan tentang sejarah pahlawan maupun daerah Sulawesi Selatan.

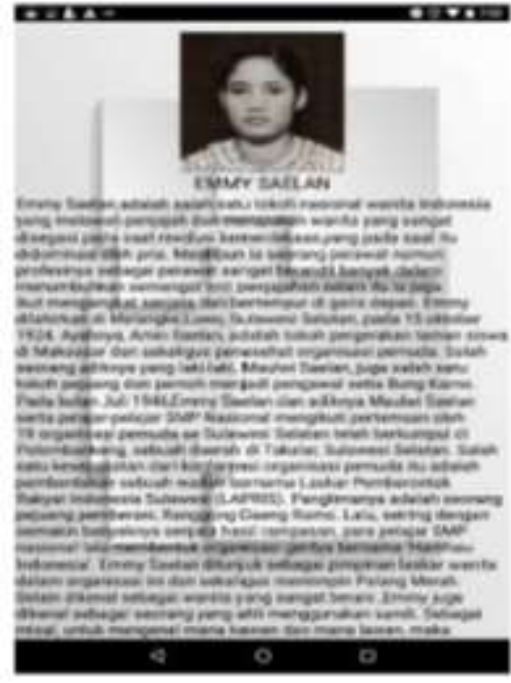

(A)

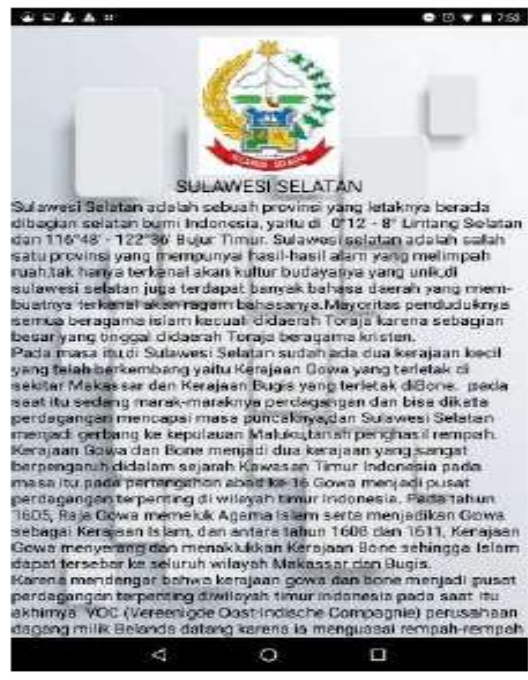

(B)

Gambar 5. Tampilan Informasi Pahlawan(A); Tampilan informasi Sulawesi Selatan(B)

Selain memberikan informasi berupa sejarah pahlawan dan informasi mengenai Sulawesi Selatan. Sistem ini juga memberikan kemudahan pengguna untuk dapat mengunjungi lokasi sejarah yang berada disulawesi Selatan dengan menginput lokasi data pengguna berada sehingga dapat menunjukaan lokasi sejarah yang ingin diketahui. Setelah mengiput lokasi maka aplikasi akan menujukkan rute yang terbaik sampai ketitik yang akan ingin dikunjungi. Berikut adalah tampilan pencarian lokasi tempat bersejarah.
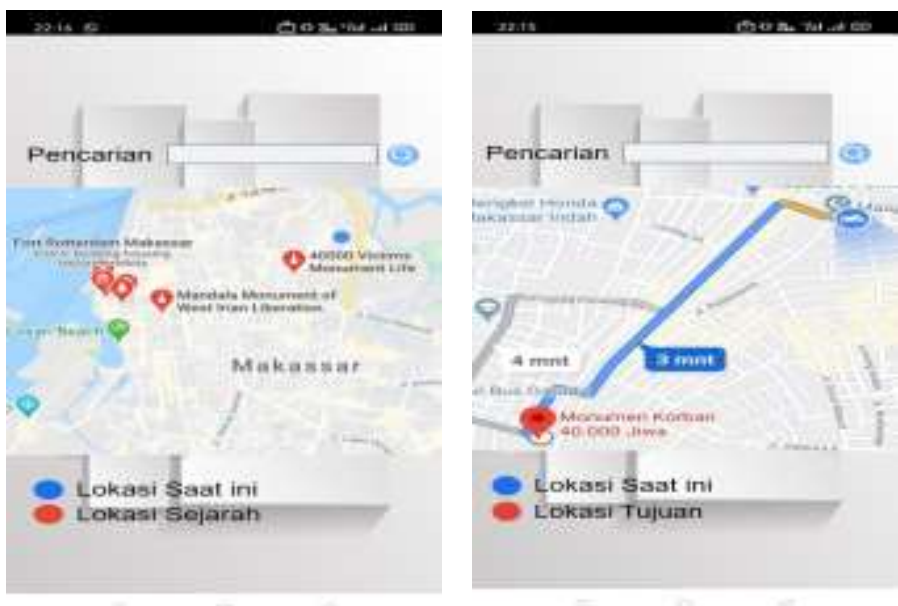

Gambar 6. Tampilan pencarian lokasi sejarah pahlawan 


\section{KESIMPULAN}

Sistem informasi sejarah pahlawan pada penelitian ini telah diaplikasikan menggunakan metode sequential search berbasis android. Metode ini dapat mempermudah pengguna dalam menentukan jalur yang tepat dalam memilih lokasi yang akan dikunjungi. Aplikasi ini memberikan informasi kepeda pengguna mengenai sejarah para pahlawan dan juga informasi mengenai daerah Sulawesi Selatan.

\section{DAFTAR PUSTAKA}

[1] Amirullah M, Aswar dan Irawan A W. 2020. Nilai - nilai Perjuangan Sultan Hasanuddin dan Syekh Yusuf AL- Makassary sebagai konstruksi identitas diri konseli Makassar. Jurnal Bimbingan dan Konseling Islam.Vol.10, No.01, Hal. 108-120.

[2] Mustika N, dan Wahyuningsih P. 2020. Penerapan metode Direct Search pada sistem informasi sejarah pahlawan Sulawesi Selatan berbasis Android. Jurnal Elektro Luceat. Vol. 6, No. 1.

[3] Gusmao A, Pramono S H, dan Sunaryo. 2013. Sistem informasi geografis pariwisata berbasis web dan pencarian jalur terpendek dengan algoritma dijkstra. Jurnal EECCIS. Vol. 7, No. 2, Hal. 125-130.

[4] Rizal M, dan Latifah F. 2017. Perancangan aplikasi lokasi wisata kota Jakarta menggunakan algoritma sequential search berbasis android. Jurnal PILAR Nusa Mandiri. Vol. 13, No. 2, Hal. 227-232.

[5] Fernando Y, Mutsaqov M A, dan Megawaty D A. 2020. Penerapan algoritma a-star pada aplikasi pencarian lokasi dibandar Lampung berbasis android. Jurnal TEKNOINFO. Vol. 14, No.1, Hal. 27-34.

[6] Utami M, dan Apridiansyah Y. 2019. Implementasi algoritma sequential searching pada sistem pelayanan puskesmas menggunakan bootsrap (studi Kasus Puskesmas Kampung Bali Bengkulu). JSAI. Vol. 2, No. 1, Hal. 81-86.

[7] Sonita A, dan Sari M. 2018. Implementasi algoritma sequential searching untuk pencarian nomor surat pada sistem arsip elektronik. Jurnal Pseudocode. Vol. 5, No. 1. Hal. 1-9.

[8] Alifuddin M, Zuhriyah S, Wahyuningsih P, dan Asrul B E W. 2019. Implementation of 3D animation for identification of coral reefs based on android mobile application. ICEASD. April 01-02, DOI 10.4108/eai.1-4-2019.2287223.

[9] Wahyuningsih P, dan Guntur. 2018. The information system of bus ticket reservation based on android application to manage the company business management. Internasional Conference and Call For Paper. Vol. 1, No. 1.

[10] Seto M H N, Listyorini T, dan Susanto A. 2015. Pengenalan pahlawan Indonesia berbasis Augmented Reality dengan marker uang Indonesia. Prosiding SNATIF ke-2. ISBN: 978-6021180-21-1. 